\title{
Application of a new method for determining the mass of oil per unit area of bottom sediments of water bodies
}

\author{
Vladislava Perminova* , Danil Vorobiev, Yulia Frank and Vladislav Perminov \\ National Research Tomsk State University, 36 Lenin Ave.,Tomsk, 634050, Russian Federation
}

\begin{abstract}
The authors of the article draw the readers' attention to the urgent problem that is the assessment of the pollution of bottom sediments of water bodies with hydrocarbons in the form of oil and oil products. When conducting surveys of water bodies, the determination of the content of oil or oil products in bottom sediments is expressed in grams per kilogram of precipitation in an air-dry state. Information in this form cannot be associated with the mass of oil at the bottom of the water body, what is very important when designing treatment works and calculating damage to aquatic biological resources. The method for determining the mass of oil pollution per unit area of bottom sediments of water bodies has been proposed and tested, what makes it possible to associate pollution not only with the concentration of pollutants, but also with the area of the reservoir.
\end{abstract}

\section{Introduction}

Currently, one of the main tasks of environmental protection in the oil and gas complex is the elimination of the consequences of oil pollution on the territories that occurred as a result of accidental spills, both fresh and belonging to the category of "historical heritage". In oil-producing regions with high lakes and a developed river network, aquatic ecosystems are primarily affected by oil and oil products pollution [1]. Oil and oil products are highly toxic, mutagenic and carcinogenic and have a negative effect on aquatic biota, especially on benthic organisms [2]. The need in conducting a qualitative analysis of bottom sediments of water bodies is enshrined in the general principles of calculating the amount of harm caused to water bodies. In 2014, the Ministry of Natural Resources of the Russian Federation approved methodological guidelines, according to which environmental monitoring of bottom sediments of water bodies of land is an integral part of the general environmental monitoring of water bodies intended for their study and protection. However, this Order does not regulate the process of determining oil at the bottom of a water body.

\footnotetext{
${ }^{*}$ Corresponding author: vladaperm18@yandex.ru
} 


\section{Materials and methods}

The methods for determining oil products in bottom sediments, in a generalized form, include the following mandatory steps: sampling bottom sediments, drying the sample to an air-dry state, extracting oil products and determining the concentration of pollutants. As a rule, sampling is regulated and should be carried out by a sampling device. Bottom sediment samples are characterized by the presence of a certain sampling area. As you know, compulsory accounting of the sampling area is used in hydrobiological research to determine the quantitative indicators of food organisms per unit area. Similarly, our proposed method [3] includes: 1) fixing the sampling area; 2) weighing the entire sample after the drying step.

After determining the content of the mass concentration of oil pollution in the analyzed sample of bottom sediments, $\mathrm{Cf}(\mathrm{g} / \mathrm{kg})$, this indicator is compared with the established regional background value for this type of bottom sediments, or with the standard for the permissible residual content of oil and oil products in bottom sediments $\mathrm{Cf}(\mathrm{g} / \mathrm{kg})$. If the value of $\mathrm{Cx}>\mathrm{Cf}$, then anthropogenic pollutants are most likely present in the bottom sediments, and then the oil content $\mathrm{C} 0(\mathrm{~g})$ in the entire sample of bottom sediments is calculated using formula 1:

$$
\mathrm{Cs}=\mathrm{C} 0 / \mathrm{Sn}=\mathrm{Mn} \times(\mathrm{Cx} \mathrm{Cf})) /(1000 \times \mathrm{Sn})
$$

$\mathrm{Mn}$ is the mass of the entire sediment sample at point $\mathrm{n}, \mathrm{g}$;

$\mathrm{C} 0$ is the mass of petroleum products in the entire sediment sample from point $\mathrm{n}, \mathrm{g}$;

$\mathrm{Sn}$ is the area of seizure of the bottom sediment instrument when sampling, $\mathrm{m}^{2}$.

$\mathrm{C}$ is the mass concentration of petroleum products measured by the instrument, $\mathrm{g} / \mathrm{kg}$

$\mathrm{Cf}$ is the fuel mass concentration of the specified regional background values for this type of bottom sediment or the allowable residue of the sediment in sediment, $\mathrm{g} / \mathrm{kg}$.

We conducted a survey of 88 oil-contaminated water bodies within the Samotlor oil field, North Russia. For selection sediment samples used corer Petersen capture area 1/80 $\mathrm{m}^{2}$ and sampler for peat deposits P 04.09 (EIJKELKAMP, Netherlands) c sample volume of 0.5 liters. To determine the type of bottom sediments was analyzed organic matter content gravimetrically. The total oil content was determined by infrared spectrophotometry. Application Example is listed in Table 1.

Table 1. Calculation of the oil mass per $1 \mathrm{~m}^{2}$ organogenic bottom sediments

\begin{tabular}{|c|c|c|}
\hline The area of the sampled bottom sediments & $\mathrm{M}^{2}$ & 0.025 \\
\hline Weight of the whole sample in air-dry & $\mathrm{g}$ & 478 \\
\hline The concentration of oil in bottom sediments & $\mathrm{g} / \mathrm{kg}$ & 38.5 \\
\hline $\begin{array}{c}\text { Regional Standard for organogenic bottom } \\
\text { sediments }\end{array}$ & $\mathrm{g} / \mathrm{kg}$ & 4.0 \\
\hline $\begin{array}{c}\text { Oil mass in the selected sample of known weight } \\
\text { with a specific area }\end{array}$ & $\mathrm{g}$ & $16.491=(38.5-4.0) \times 478 / 1000$ \\
\hline Oil mass per $1 \mathrm{~m}^{2}$ & $\mathrm{~g} / \mathrm{m}^{2}$ & $659.64=16.491 / 0.025$ \\
\hline
\end{tabular}

\section{Results}

Concentrations of oil products in the bottom sediments of the surveyed lakes exceed the background values $(0.5 \mathrm{~g} / \mathrm{kg})$. The minimum value of the total content of oil products in the 
bottom sediments was $1.5 \mathrm{~g} / \mathrm{kg}$ (in one of the samples taken from the unnamed lake No. 72); the maximum values were higher than $300 \mathrm{~g} / \mathrm{kg}$ (in the samples from the unnamed lakes No. 22 and No. 99). The results of calculations of the oil content in bottom sediments of water bodies are presented in Table 2 .

Table 2. Average values of the oil content in the reservoirs, the calculated new method

\begin{tabular}{|c|c|c|c|c|c|c|c|}
\hline \multicolumn{6}{|c|}{ Organogenic sediments } & \multicolumn{2}{|c|}{$\begin{array}{c}\text { Sediments of mixed } \\
\text { composition }\end{array}$} \\
\hline $\begin{array}{c}\text { Water } \\
\text { body, } \\
\text { No. }\end{array}$ & $\begin{array}{l}\text { Petroleum, } \\
\mathrm{g} / \mathrm{m}^{2}\end{array}$ & $\begin{array}{c}\text { Water } \\
\text { body, } \\
\text { No. }\end{array}$ & $\begin{array}{l}\text { Petroleum, } \\
\mathrm{g} / \mathrm{m}^{2}\end{array}$ & $\begin{array}{c}\text { Water } \\
\text { body, } \\
\text { No. }\end{array}$ & $\begin{array}{l}\text { Petroleum, } \\
\mathrm{g} / \mathrm{m}^{2}\end{array}$ & $\begin{array}{c}\text { Water } \\
\text { body, } \\
\text { No. }\end{array}$ & $\begin{array}{l}\text { Petroleum, } \\
\mathrm{g} / \mathrm{m}^{2}\end{array}$ \\
\hline 4 & 12.7 & 78 & 201.3 & 23 & 12.4 & 87 & 8.6 \\
\hline 7 & 18.0 & 79 & 2.1 & 33 & 1.2 & 95 & 45.0 \\
\hline 15 & 5.1 & 93 & 10.7 & 38 & 20.1 & 100 & 82.4 \\
\hline 31 & 8.8 & 1 & 6.9 & 44 & 2.8 & 2 & 324.1 \\
\hline 37 & 9.6 & 12 & 10.5 & 55 & 14.9 & 84 & 77.5 \\
\hline 48 & 5.0 & 21 & 1.1 & 62 & 28.2 & 24 & 822.1 \\
\hline 59 & 20.3 & 26 & 50.7 & 73 & 44.8 & 76 & 87.6 \\
\hline 67 & 246.9 & 36 & 23.8 & 80 & 43.1 & 83 & 0.1 \\
\hline 72 & 2.8 & 49 & 36.4 & 81 & 27.4 & 91 & 302.3 \\
\hline 74 & 11.9 & 53 & 6.5 & 82 & 10.2 & 99 & 58.0 \\
\hline 75 & 36.4 & 65 & 203.7 & 85 & 16.3 & 101 & 27.7 \\
\hline 88 & 37.9 & 66 & 61.6 & 92 & 27.0 & 8 & 2.8 \\
\hline 19 & 2.7 & 69 & 157.2 & 96 & 5.4 & 34 & 576.7 \\
\hline 28 & 3.4 & 71 & 24.8 & 17 & 170.2 & 46 & 256.3 \\
\hline 42 & 4.1 & 90 & 25.2 & 60 & 350.8 & 35 & 115.9 \\
\hline 43 & 21.0 & 98 & 40.3 & 61 & 120.6 & - & - \\
\hline 56 & 67.2 & 3 & 17.4 & 9 & 3.8 & - & - \\
\hline 58 & 3.4 & 14 & 1.4 & 13 & 12.7 & - & - \\
\hline 68 & 0.0 & 18 & 11.6 & 16 & 8.2 & - & - \\
\hline 70 & 3.3 & 22 & 423.1 & 20 & 3.4 & - & - \\
\hline 29 & 5.3 & 51 & 0.1 & 86 & 15.3 & - & - \\
\hline 30 & 11.9 & 52 & 13.8 & 94 & 2.0 & - & - \\
\hline 41 & 88.6 & 57 & 1.0 & 51 & 0.1 & - & - \\
\hline
\end{tabular}




\begin{tabular}{|l|l|l|l|l|l|l|l|}
\hline 45 & 19.9 & 89 & 82.9 & 50 & 12.1 & - & - \\
\hline 47 & 14.4 & 40 & 3.9 & 29 & 5.3 & - & - \\
\hline
\end{tabular}

Among the surveyed water bodies, lakes with organogenic bottom sediments prevail. The minimum value of $0.1 \mathrm{~g} / \mathrm{m}^{2}$ is recorded in unnamed lake No. 51. The maximum values of pollution equal to $841.5 \mathrm{~g} / \mathrm{m}^{2}$ characterize unnamed lake No. 89 . Average number of oil per $1 \mathrm{~m}^{2}$ organogenic sediments was $41.5 \mathrm{~g}$.

In lakes in which bottom sediments are classified as mixed and mineral, the minimum value $-0.1 \mathrm{~g} / \mathrm{m}^{2}$. However, the maximum value of the oil mass is $1536.6 \mathrm{~g} / \mathrm{m}^{2}$ (unnamed lake No. 24) and average pollution value $-185.8 \mathrm{~g} / \mathrm{m}^{2}$.

\section{Discussion and conclusion}

Thus, the proposed method for determining the mass of oil pollution per unit area of bottom sediments of water bodies makes it possible to carry out calculations that are necessary not only to understand the degree of pollution of the bottom of a water body, but also to determine the amount of damage caused to a water body. Theoretical results can be verified when cleaning small lakes from oil pollution, for example using flotation technology [4].

Attention should be paid to the absence in most regions of the Russian Federation of established regional standards for the permissible residual content of oil and oil products in bottom sediments, which may be a limitation of the applicability of the method.

The reported study was funded by RFBR, project number 20-34-90076.

\section{References}

1. Y.A. Frank, S.V. Lushnikov, D.S. Vorobiev, T.A. Mongolina, L.V. Lukyantseva, Y.A. Noskov, Water purification. Water treatment. Water supply, 3, 64-71 (2009).

2. Y.A. Noskov, Y.S. Nikulina, R.E. Romanov, M.D. Tumanov, D.S. Vorobiev, Ukrainian J. of Ecology, 2, 383-391 (2018)

3. D.S. Vorobiev, V.V. Perminova, Ecology and Industry of Russia, 24(12), 28-31 (2020)

4. Y.A. Frank, D.S. Vorobiev, O.E. Merzlyakov, F.R. Sataev, A.A. Trifonov, E.O. Kopylov, K.V. Stryuk, E.A. Kalinovskaya, S.V. Gronskiy, O.V. Chibrikov, V.V. Perminova, Y.V. Branevskiy, S.P. Kulizhskiy, T.S. Hunter, Water Science and Technology, 82(12), 3062-3073 (2020) 